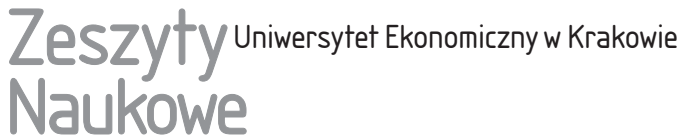

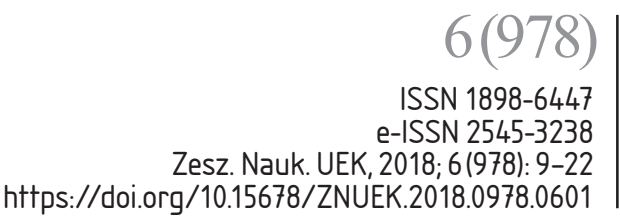

Piotr Rubaj

Viktoriya Voytsekhovska

\section{Ukraina wobec wyzwań gospodarczych i politycznych}

\section{Streszczenie}

Celem artykułu jest dokonanie oceny obecnej sytuacji gospodarczej i politycznej na Ukrainie oraz prezentacja potencjalnych kierunków rozwoju tego kraju. Dla poprawy poziomu życia obywateli i wzrostu ich poczucia bezpieczeństwa niezbędne są głębokie reformy wewnętrzne, zbliżenie w relacjach z Unią Europejską oraz zakończenie konfliktu zbrojnego w Donbasie. Procesy te są bardzo złożone w bieżących uwarunkowaniach geopolitycznych, zatem osiągnięcie widocznego postępu w krótkim czasie będzie bardzo trudne. Sytuacja na Ukrainie ma również bardzo ważne znaczenie dla Polski jako kraju sąsiedzkiego, dlatego w artykule zawarte zostały implikacje sytuacji gospodarczej i politycznej na Ukrainie dla Polski.

Słowa kluczowe: Ukraina, kryzys ukraiński, polityka gospodarcza na Ukrainie, relacje Polska-Ukraina.

Klasyfikacja JEL: F00, F02, F15, F47.

\section{Wprowadzenie}

Wydarzenia z ostatnich kilku lat na Ukrainie, począwszy od fali społecznych protestów w listopadzie 2013 r. z powodu odłożenia przez prezydenta W. Januko-

Piotr Rubaj, Katolicki Uniwersytet Lubelski Jana Pawła II, Wydział Nauk Społecznych, Katedra Ekonomii Międzynarodowej, al. Racławicka 14, 20-950 Lublin, e-mail: p.rubaj@kul.pl

Viktoriya Voytsekhovska, Politechnika Lwowska, Katedra Ekonomii Przedsiębiorstwa i Inwestycji, Stepana Bandery 12, L'viv, L'vivs'ka oblast, 79000, Ukraina, e-mail: viktoriia.v.voitsekhovska@ lpnu.ua 
wycza podpisania umowy stowarzyszeniowej z UE, sprawiły, że kraj ten znalazł się w centrum zainteresowań nie tylko bezpośrednich sąsiadów, ale całego świata. Aneksja Krymu przez Rosję, pogwałcenie przez nią międzynarodowych umów i traktatów, a także przedłużający się konflikt w Donbasie spowodowały, że świat po kilkunastu latach odprężenia w relacjach Wschód-Zachód wrócił na ścieżkę konfrontacji. Obecna sytuacja polityczna i gospodarcza na Ukrainie ma nie tylko kluczowe znaczenie dla tego kraju, ale również w istotny sposób wpływa na równowagę sił w stosunkach międzynarodowych oraz zapewnienie bezpieczeństwa i pokoju w Europie, a nawet na świecie. Wydarzenia na Majdanie w 2013 r. sprawiły, że Ukraina wybiła się na niezależność od Moskwy, ale jednocześnie stanęła w obliczu zupełnie nowych wyzwań i problemów. Wtargnięcie Rosji na Ukrainę i aneksja Krymu to pierwszy przypadek w XXI w., gdy obce mocarstwo dokonało w sposób siłowy zmiany granic innego kraju europejskiego, łamiąc wszystkie wcześniejsze gwarancje bezpieczeństwa i integralności terytorialnej (Czaja 2016, s. 25). To sytuacja bezprecedensowa, zagrażająca bezpieczeństwu międzynarodowemu. Działania Rosji doprowadziły po kilkunastu latach względnego spokoju do ponownego zaognienia sytuacji w stosunkach Wschód-Zachód i wprowadzenia przez państwa należące do NATO i UE sankcji politycznych i gospodarczych w stosunku do agresora. W zaistniałej sytuacji Ukraina jest krajem, który staje w obliczu trudnych i strategicznych decyzji. Z jednej strony musi zmierzyć się z problemami zewnętrznymi związanymi z sytuacją międzynarodową, z drugiej zaś - powinna podjąć wyzwania dotyczące wewnętrznych reform, które pozwolą na rozwój gospodarczy i wzrost poziomu życia obywateli. Problem zmian strukturalnych wydaje się szczególnie ważny w sytuacji, kiedy gospodarka Ukrainy jest w stanie kryzysu i wymaga szybkich i skutecznych reform, które zapoczątkowałyby trwały wzrost gospodarczy (Yakubovskiy i in. 2017, s. 13).

Wydarzenia, które miały miejsce na Ukrainie w ostatnich kilku latach, oraz obecna sytuacja mają również strategiczne znaczenie dla Polski jako kraju sąsiedzkiego, a ponadto członka UE i NATO. Analiza tych wydarzeń ma więc wymiar praktyczny dla Polski w kilku aspektach: gospodarczym, politycznym i bezpieczeństwa. Celem rozważań zawartych w niniejszym opracowaniu jest analiza bieżącej sytuacji gospodarczej na Ukrainie, prognozowanie potencjalnych kierunków zmian oraz ich konsekwencji dla Polski. Zgodnie z główną hipotezą badawczą obecnie Ukraina znajduje się w obliczu ważnych i strategicznych decyzji politycznych i gospodarczych, które musi podjąć, aby umożliwić zrównoważony wzrost gospodarczy i rozwój społeczny. Dodatkowo sformułowano dwie hipotezy pomocnicze:

1. Wejście Ukrainy na ścieżkę rozwoju gospodarczo-społecznego wymaga zmiany struktury jej gospodarki w kierunku bardziej innowacyjnej, opartej na wiedzy i nowoczesnych technologiach. 
2. Dla Polski jako kraju sąsiedzkiego ważne jest strategiczne partnerstwo gospodarcze i polityczne z Ukrainą, którego celem jest zwiększenie wymiany handlowej.

Zastosowana w opracowaniu metodologia obejmuje analizę danych statystycznych pochodzących z ukraińskich i europejskich źródeł, omówienie międzynarodowych raportów dotyczących konkurencyjności oraz prognozowanie potencjalnych kierunków rozwoju ekonomicznego.

\section{Obecna sytuacja ekonomiczna na Ukrainie}

Społeczeństwo Ukrainy być może bardziej niż społeczeństwo jakiegokolwiek innego kraju europejskiego odczuwa skutki kryzysu ostatnich lat. Spowolnienie rozwoju gospodarczego, wojna na wschodzie państwa i aneksja Krymu nie skłaniają do optymizmu. Kluczowe wskaźniki rozwoju społecznego dowodzą, że dalsza poprawa sytuacji politycznej, gospodarczej i demograficznej w kraju jest niezbędna. Problemy związane z wdrażaniem programu reform są skomplikowane i trudne.

Sytuacja społeczna na Ukrainie jest determinowana zarówno przez czynniki strukturalne, jak i przez poziom życia obywateli. Wśród tych pierwszych istotną rolę odgrywa ogólna konfiguracja kluczowych czynników gospodarczych w kraju, a także wpływ warunków zewnętrznych. Trudności gospodarcze, korupcja i nieefektywne zarządzanie to według Ukraińców główne problemy, z którymi musi sobie poradzić państwo. Ukraina stoi w obliczu poważnych wyzwań, takich jak: optymalizacja systemu politycznego, wzmocnienie zasad konstytucyjnych, wzmocnienie stabilności politycznej i działania na rzecz poszanowania zasad demokracji. Ukraińskiemu społeczeństwu brakuje efektywnych środków ochrony swoich interesów, skutecznych związków zawodowych i innych instytucji obywatelskich. Problemy stwarza również nieefektywny system sądowniczy, który wymaga reform, by stać się wiarygodnym narzędziem ochrony praw obywateli (Boczi 2014, Havrylyshyn 2014).

Szacuje się, że utrata Krymu spowodowała na Ukrainie zmniejszenie ludności (o 4,3\%), spadek handlu zagranicznego (o 1,5-16\%) i PKB (o 4\%). Spadek dynamiki wzrostu gospodarki jest wyraźnie widoczny na tle innych krajów regionu w latach 2014-2016 (tabela 1). Źródła naukowe podają pięć głównych czynników hamujących rozwój ukraińskiej gospodarki: szara strefa (stanowi ok. 47\% PKB), duża skala korupcji (13,1\% PKB), świadczenia emerytalne z budżetu (7,5\% PKB), obsługa długu publicznego (7,4\% PKB) i bardzo wysoka energochłonność, większa 3-5 razy od energochłonności krajów rozwiniętych. Główne wskaźniki makroekonomiczne odzwierciedlają bieżącą sytuację społeczną. W 2017 r. wzrost PKB 
Tabela 1. Dynamika wzrostu PKB Ukrainy na tle Unii Europejskiej i innych krajów regionu w latach 2006-2016

\begin{tabular}{|l|c|c|c|c|c|c|c|c|c|c|c|}
\hline Wyszczególnienie & 2006 & 2007 & 2008 & 2009 & 2010 & 2011 & 2012 & 2013 & 2014 & 2015 & 2016 \\
\hline UE-28 $^{2}$ & 3,3 & 3,0 & 0,4 & $-4,3$ & 2,1 & 1,7 & $-0,4$ & 0,3 & 1,8 & 2,3 & 2,0 \\
\hline Armenia $^{\mathrm{a}}$ & 13,2 & 13,7 & 6,9 & $-14,1$ & 2,2 & 4,7 & 7,2 & 3,3 & 3,6 & 3,2 & 0,2 \\
\hline Azerbejdżan $^{\mathrm{b}}$ & 34,5 & 25,0 & 10,8 & 9,3 & 5,0 & 0,1 & 2,2 & 5,8 & 2,8 & 1,1 & $-3,1$ \\
\hline Białoruśs $^{\mathrm{c}}$ & 10,0 & 8,6 & 10,2 & 0,2 & 7,7 & 5,5 & 1,7 & 1,0 & 1,7 & $-3,8$ & $-2,6$ \\
Gruzja $^{\mathrm{d}}$ & 9,4 & 12,6 & 2,4 & $-3,7$ & 6,2 & 7,2 & 6,4 & 3,4 & 4,6 & 2,9 & 2,7 \\
Mołdawia $^{\mathrm{d}}$ & 4,8 & 3,0 & 7,8 & $-6,0$ & 7,1 & 6,8 & $-0,7$ & 9,4 & 4,8 & $-0,4$ & 4,3 \\
Ukraina $^{\mathrm{e}}$ & 7,6 & 8,2 & 2,2 & $-15,1$ & 4,1 & 5,4 & 0,2 & 0,0 & $-6,6$ & $-9,8$ & 2,3 \\
\hline
\end{tabular}

a dane za lata 2006-2011 według systemu rachunków narodowych z 1993 r.; b dane za lata 2006-2015 według systemu rachunków narodowych z 1993 r.; c dane za lata 2006-2008 według systemu rachun-

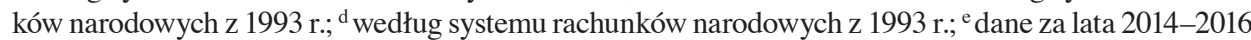
z wyłączeniem zaanektowanego nielegalnie Krymu, miasta Sewastopol oraz terytoriów, które pozostawały poza kontrolą Ukrainy.

Źródło: (Statistics on European Neighbourhood... 2018, s. 59).

Tabela 2. Stopa bezrobocia na Ukrainie na tle Unii Europejskiej i innych krajów regionu w latach 2006-2016

\begin{tabular}{|c|c|c|c|c|c|c|c|c|c|c|c|}
\hline Wyszczególnienie & 2006 & 2007 & 2008 & 2009 & 2010 & 2011 & 2012 & 2013 & 2014 & 2015 & 2016 \\
\hline UE-28 & 8,2 & 7,1 & 7,0 & 8,9 & 9,5 & 9,6 & 10,4 & 10,8 & 10,2 & 9,4 & 8,6 \\
\hline Armenia $^{a}$ & 28,1 & 30,0 & 17,2 & 19,6 & 19,8 & 16,6 & 17,9 & 16,9 & 17,6 & 18,5 & 18,0 \\
\hline Azerbejdżan & 6,6 & 6,3 & 5,9 & 5,7 & 5,6 & 5,4 & 5,2 & 5,0 & 4,9 & 5,0 & 5,0 \\
\hline Białoruś $^{b}$ & 1,4 & 1,1 & 0,9 & 0,9 & 0,8 & 0,7 & 0,6 & 0,5 & 0,5 & 0,9 & 5,8 \\
\hline Gruzja $^{c}$ & 13,6 & 13,3 & 16,5 & 16,9 & 16,3 & 15,1 & 15,0 & 14,6 & 12,4 & 12,0 & 11,8 \\
\hline Mołdawia & 7,4 & 5,1 & 4,0 & 6,4 & 7,4 & 6,7 & 5,6 & 5,1 & 3,9 & 4,9 & 4,2 \\
\hline Ukraina $^{\mathrm{d}}$ & 6,8 & 6,4 & 6,4 & 8,8 & 8,1 & 7,9 & 7,5 & 7,2 & 9,3 & 9,1 & 9,3 \\
\hline
\end{tabular}

a 2006 r. - nieważony wynik ankiety; 2007 r. - osoby w wieku 16-75 lat; 2008-2013 - osoby w wieku 15-75 lat; 2008 i 2014 r. - niepełne dane; b 2006-2015 - bezrobocie rejestrowane; 2016 r. - niepełne dane; ' osoby w wieku 15 lat i więcej; ${ }^{\mathrm{d}}$ osoby w wieku 15-70 lat; dane za lata 2014-2016 z wyłączeniem zaanektowanego nielegalnie Krymu, miasta Sewastopol oraz terytoriów, które pozostawały poza kontrolą Ukrainy.

Źródło: (Statistics on European Neighbourhood... 2018, s. 50).

wyniósł ponad 2\%, co odpowiada średniej stopie wzrostu w krajach regionu, i jest to znacznie lepsza sytuacja w porównaniu z 2014 r., kiedy odnotowano spadek o prawie $17 \%$. Jednocześnie poziom PKB per capita na Ukrainie jest jednym z najniższych w Europie - w 2016 roku wynosił zaledwie 1974 USD i był jednym z najniższych w regionie (Statistics on European Neighbourhood... 2018). Analiza 
innych kluczowych w analizie makroekonomicznych wskaźników potwierdza stawianą wcześniej tezę, że gospodarka Ukrainy wymaga pilnych i radykalnych reform, aby wkroczyć na ścieżkę stabilnego wzrostu gospodarczego oraz wyraźnej poprawy jakości życia społeczeństwa. Ważną kwestią jest stabilizacja rynku pracy oraz finansów publicznych. Poziom bezrobocia w latach 2014-2016 utrzymywał się na poziomie powyżej $9 \%$, co było przeciętnym wynikiem w regionie oraz wartością powyżej średniej dla krajów UE (tabela 2). Deficyt budżetowy w 2016 r. wyniósł $-1,9 \%$ i także przekraczał wartości innych krajów w regionie. Dużym problemem dla Ukrainy w latach 2013-2016 był również bardzo dynamiczny wzrost poziomu inflacji, która w najbardziej krytycznym okresie - 2015 r. - osiągnęła poziom 50\%, aby w kolejnym roku spaść do poziomu kilkunastu procent (Statistics on European Neighbourhood... 2018). Niekorzystna sytuacja polityczna, zmienna dynamika wzrostu gospodarczego i wysoka inflacja we wspomnianym okresie skutecznie zniechęciły inwestorów zagranicznych. Napływ bezpośrednich inwestycji zagranicznych w 2014 r. osiągnął rekordowo niski poziom 310 mln EUR, przy średniej wartości dla lat 2010-2016 3714 mln EUR.

Tabela 3. Deficyt finansów publicznych na Ukrainie na tle Unii Europejskiej i innych krajów regionu w latach 2006-2016

\begin{tabular}{|l|c|c|c|c|c|c|c|c|c|c|c|}
\hline Wyszczególnienie & 2006 & 2007 & 2008 & 2009 & 2010 & 2011 & 2012 & 2013 & 2014 & 2015 & 2016 \\
\hline UE-28 & $-1,6$ & $-0,9$ & $-2,5$ & $-6,6$ & $-6,4$ & $-4,6$ & $-4,2$ & $-3,3$ & $-3,0$ & $-2,4$ & $-1,7$ \\
\hline Armenia & $-1,3$ & $-1,5$ & $-0,7$ & $-7,5$ & $-5,0$ & $-2,8$ & $-1,5$ & $-1,5$ & $-1,9$ & $-4,8$ & $-5,5$ \\
\hline Azerbejdżan & 0,4 & $-0,3$ & 0,0 & $-0,5$ & $-0,9$ & $-0,6$ & $-0,2$ & 0,6 & $-0,5$ & $-0,5$ & $-0,4$ \\
\hline Białoruś a $^{a}$ & 1,4 & 0,4 & 1,4 & $-0,7$ & $-2,5$ & 2,0 & 0,5 & 0,2 & 1,0 & 1,8 & 1,3 \\
\hline Gruzja & 2,7 & 0,3 & $-2,0$ & $-6,5$ & $-4,5$ & $-0,9$ & $-0,6$ & $-1,1$ & $-2,0$ & $-1,1$ & $-1,4$ \\
\hline Mołdawia & $-0,3$ & $-0,2$ & $-1,0$ & $-6,3$ & $-2,5$ & $-2,4$ & $-2,1$ & $-1,8$ & $-1,7$ & $-2,2$ & - \\
\hline Ukraina & $-1,0$ & $-0,6$ & $-1,6$ & $-5,6$ & $-6,3$ & $-2,2$ & $-3,7$ & $-4,1$ & $-4,5$ & $-0,8$ & $-1,9$ \\
\hline
\end{tabular}

${ }^{\mathrm{a}}$ wyliczenia z uwzględnieniem skonsolidowanej nadwyżki/deficytu w Białorusi.

Źródło: (Statistics on European Neighbourhood... 2018, s. 62).

Modernizacja i wzrost konkurencyjności ukraińskiej gospodarki to bardzo ważne zadania, które wymagają skomplikowanych decyzji. Jedynie konkurencyjna gospodarka może zapewnić europejskie standardy życia i wpływać kompleksowo na poziom życia, a także respektowanie praw człowieka. Kluczowe standardy społeczne i gwarancje w odniesieniu do dochodów (płaca minimalna, emerytura minimalna, pomoc dla bezrobotnych itd.) rosną, ale tempo tego wzrostu nie jest wystarczające. Dodajmy, że stosunek liczby emerytów do pracowników (1 do 14) należy do najbardziej niekorzystnych w Europie, stąd kwestia reformy emerytalnej staje się bardzo pilna. Społeczeństwo ukraińskie jest bardzo spolaryzowane, jeśli 
chodzi o poziom dochodów. Jedni żyją w biedzie, a inni w luksusie i istnieje ryzyko uzyskiwania wysokich dochodów przez część społeczeństwa w sposób niezgodny z prawem (Havrylyshyn 2014).

W związku z tym, że gospodarka Ukrainy musi stać się konkurencyjna, aby zmniejszać dzielące ją od krajów zachodnich dysproporcje, powinna znaleźć takie dziedziny, w których będzie miała przewagę gospodarczą lub społeczną. Koniecznym sposobem dalszego rozwoju jest przejście do modelu gospodarczego opartego na wiedzy i nowoczesnych technologiach. Państwo powinno promować rozwój kapitału ludzkiego, nowoczesną naukę oraz ich współdziałanie z innowacyjnymi przedsiębiorstwami.

\section{Analiza SWOT strategicznych priorytetów dla Ukrainy}

Opracowana przez A.S. Humphreya w latach 60. XX w. analiza SWOT jest podstawowym modelem, który umożliwia ocenę mocnych i słabych strony, jak również potencjalnych szans i zagrożeń organizacji czy państwa. $Z$ tego powodu analiza SWOT jest czasami nazywana analizą wewnętrzno-zewnętrzną. Po zakończeniu analizy SWOT ustala się, co może pomóc państwu w osiąganiu jego celów oraz jakie przeszkody należy pokonać lub jakie zagrożenia zminimalizować, by osiągnąć pożądane rezultaty (Chermack i Kasshanna 2007).

Analiza SWOT, stanowiąca istotny element oceny pozycji strategicznej państwa w kontekście sytuacji międzynarodowej, powinna być oparta na ocenie głównych czynników strategicznych, takich jak:

- mocne strony państwa (strong points - S),

- słabe strony państwa (weaknesses - W),

- szanse (możliwości) państwa (opportunities - O),

- zagrożenia państwa (threats - T).

$\mathrm{Na}$ podstawie analizy literatury przedmiotu oraz danych zawartych w pracy (The Global Competitiveness... 2016) dokonano próby określenia obecnej sytuacji na Ukrainie, stosując analizę SWOT (tabela 4).

Następnie możemy zapisać poszczególne czynniki w formie macierzy, przypisując im następujące punkty: 0 - brak oddziaływania, 1 - słabe oddziaływanie, 2 - silne oddziaływanie. Macierz SWOT (tabela 5) jest rezultatem opracowania zamieszczonego w tabeli 4, gdzie S oznacza mocne strony, W - słabe strony, $\mathrm{O}$ - możliwości, T - zagrożenia.

Analizując macierz SWOT, należy przede wszystkim zwrócić uwagę na komórki zawierające wielkości 2 i 1, które są najważniejsze. Na przykład przecięcie komórek S3 i O5 (trzeci rząd i piąta kolumna macierzy) oznacza, że poziom wykształcenia i jakość kapitału ludzkiego ma znaczący wpływ na reformowanie gospodarki. 
W ten sam sposób możemy przewidzieć wpływ mocnych i słabych stron na szanse i zagrożenia. Przecięcie komórek W1 i T5 oznacza, że poziom korupcji znacząco wpływa na wzrost szarej strefy w gospodarce, co jest tendencją negatywną.

Tabela 4. Analiza SWOT uwzględniająca słabe i mocne strony, a także możliwości i zagrożenia w odniesieniu do Ukrainy

\begin{tabular}{|c|c|}
\hline Mocne strony & Słabe strony \\
\hline $\begin{array}{l}\text { S1. Wzrost internacjonalizacji ukraińskich } \\
\text { przedsiębiorstw }\end{array}$ & W1. Wysoki poziom korupcji \\
\hline S2. Efektywność rynku dóbr & W2. Niski poziom PKB per capita \\
\hline $\begin{array}{l}\text { S.3. Poziom wykształcenia i jakość kapitału } \\
\text { ludzkiego }\end{array}$ & W3. Wysoka energochłonność PKB \\
\hline S4. Atrakcyjne warunki agronomiczne & W4. Wysoka zależność gospodarki od importu \\
\hline S5. Rozmiar rynku & W5. Znaczny poziom inflacji \\
\hline S6. Wysoki potencjał naukowy ${ }^{a}$ & W6. Niedoskonałość systemu finansowego \\
\hline $\begin{array}{l}\text { S7. Baza surowców do produkcji energii } \\
\text { odnawialnej }\end{array}$ & W7. Niski poziom wolności gospodarczej \\
\hline Szanse (możliwości) & Zagrożenia \\
\hline O1. Rozwój działalności zagranicznej & $\begin{array}{l}\text { T1. Wzrost zależności finansowej } \\
\text { i ekonomicznej od Rosji }\end{array}$ \\
\hline $\begin{array}{l}\text { O2. Rozwój zaawansowanej technologicznie } \\
\text { produkcji przemysłowej }\end{array}$ & T2. Agresja ze strony Rosji \\
\hline O3. Poprawa atrakcyjności inwestycyjnej & T3. Niestabilność polityczna i społeczna \\
\hline O4.Zwiększenie niezależności energetycznej & $\begin{array}{l}\text { T4. Dalsza nierównowaga w strukturze } \\
\text { gospodarki }\end{array}$ \\
\hline O5. Reformowanie gospodarki & T5. Wzrost szarej strefy \\
\hline O6. Poprawa działalności eksportowej & T6. Wzrost emigracji \\
\hline O7. Polityka zrównoważonego rozwoju & T7. Spadek demograficzny \\
\hline
\end{tabular}

${ }^{a}$ na wysoki potencjał naukowy jako mocną stronę wskazano w opracowaniu (Meshko i Kostiuchenko 2015, s. 74).

Źródło: opracowanie własne.

Analiza silnych i słabych stron zaprezentowanych w tabeli 4 wykazała, że Ukraina ma spory potencjał gospodarczy, ale rozwój jej gospodarki będzie możliwy po zminimalizowaniu szarej strefy. Widoczne są też zjawiska, które trudno bagatelizować, takie jak zagrożenie zewnętrzne czy dług państwowy. Dążenie do zmniejszenia negatywnego wpływu korupcji na gospodarkę jest ważnym warunkiem osiągnięcia sukcesu. Na podstawie analizy SWOT można wskazać następujące zadania, które stoją przed gospodarką Ukrainy: 
- zwiększenie atrakcyjności inwestycyjnej dzięki wykorzystaniu np. dobrych warunków klimatycznych, dużego rynku, wysokiej jakości kapitału ludzkiego,

- zwiększenie innowacyjnej i wysokotechnologicznej produkcji dzięki wykorzystaniu badań naukowych, przy jednoczesnym zmniejszeniu energochłonności PKB,

- wykorzystanie korzystnych warunków agronomicznych w rolnictwie, a także osiągnięć z zakresu biotechnologii,

- wykorzystanie bazy surowcowej do produkcji energii odnawialnej, co spowoduje zmniejszenie zależności energetycznej i pozwoli reformować gospodarkę.

Tabela 5. Macierz SWOT dla Ukrainy (analiza danych za lata 2013-2016)

\begin{tabular}{|c|c|c|c|c|c|c|c|c|c|c|c|c|c|c|}
\cline { 2 - 16 } \multicolumn{1}{c|}{} & O1 & O2 & O3 & O4 & O5 & O6 & O7 & T1 & T2 & T3 & T4 & T5 & T6 & T7 \\
\hline S1 & 1 & 0 & 2 & 0 & 1 & 0 & 0 & 0 & 1 & 0 & 0 & 0 & 0 & 0 \\
\hline S2 & 2 & 0 & 1 & 0 & 1 & 1 & 0 & 0 & 0 & 0 & 0 & 1 & 1 & 0 \\
\hline S3 & 0 & 2 & 1 & 0 & 2 & 0 & 1 & 0 & 0 & 1 & 1 & 1 & 1 & 0 \\
\hline S4 & 0 & 0 & 2 & 0 & 1 & 2 & 1 & 0 & 1 & 0 & 2 & 0 & 0 & 0 \\
\hline S5 & 2 & 1 & 2 & 0 & 0 & 1 & 0 & 1 & 0 & 0 & 1 & 1 & 0 & 0 \\
\hline S6 & 0 & 2 & 0 & 2 & 0 & 0 & 1 & 0 & 0 & 0 & 0 & 0 & 2 & 0 \\
\hline S7 & 0 & 1 & 0 & 2 & 1 & 0 & 2 & 1 & 0 & 0 & 0 & 1 & 0 & 0 \\
\hline W1 & 1 & 0 & 2 & 0 & 1 & 0 & 0 & 0 & 0 & 1 & 0 & 2 & 1 & 0 \\
\hline W2 & 0 & 0 & 1 & 0 & 2 & 0 & 1 & 0 & 0 & 1 & 0 & 0 & 2 & 1 \\
\hline W3 & 0 & 2 & 1 & 2 & 2 & 0 & 1 & 0 & 0 & 0 & 1 & 0 & 0 & 0 \\
\hline W4 & 1 & 1 & 0 & 0 & 2 & 0 & 0 & 2 & 0 & 0 & 1 & 0 & 0 & 0 \\
\hline W5 & 1 & 0 & 1 & 0 & 1 & 1 & 0 & 1 & 0 & 1 & 0 & 1 & 1 & 1 \\
\hline W6 & 1 & 0 & 1 & 0 & 2 & 1 & 0 & 1 & 0 & 0 & 1 & 1 & 0 & 0 \\
\hline W7 & 2 & 1 & 1 & 0 & 1 & 1 & 0 & 0 & 0 & 1 & 1 & 2 & 2 & 1 \\
\hline
\end{tabular}

Źródło: opracowanie własne na podstawie tabeli 4.

Za ważne należy uznać reformowanie i transformację gospodarki w kierunku stałego rozwoju, tzn. od ładu liniowego do circular economy, zmniejszenie nierówności socjalnych itd. (Boczi 2014, Yagelskaya Yu 2013).

Wykorzystanie silnych stron państwa pozwoli zahamować regres, ograniczyć zagrożenia zewnętrzne, a także zreformować gospodarkę narodową oraz zrealizować ideę trwałego i zrównoważonego rozwoju społeczno-gospodarczego.

\section{Relacje gospodarcze Polski z Ukrainą}

Pomimo że Ukraina jest jednym z największych krajów Europy, którego liczba ludności przed aneksją Krymu i separacją Donbasu wynosiła ponad $45 \mathrm{mln}$ 
(w 2016 r. spadła do $43 \mathrm{mln}$ ) (European Commission, Directorate-General for Trade 2017), to pod względem rozwoju gospodarczego daleko jej do najbogatszych gospodarek kontynentu. W 2015 r. PKB per capita w wypadku tego kraju wynosiło 1907 EUR, przy średniej dla wszystkich krajów UE w wysokości 28700 EUR, a dla Polski - 11315 EUR (Statistics Explained... 2016). Dla krajów w tym regionie wartości te wynosiły odpowiednio (w EUR): Armenia - 3156, Azerbejdżan - 5012, Białoruś - 5204, Gruzja - 3371, Mołdawia - 1645. Ukraina nawet $\mathrm{w}$ regionie nie należy zatem do najbogatszych państw, nie mówiąc już o porównaniu jej PKB ze średnią dla wszystkich krajów Wspólnoty.

Dla Polski Ukraina z jednej strony jest krajem sąsiedzkim i potencjalnie strategicznym partnerem gospodarczym, z drugiej - kluczowym partnerem politycznym w relacjach wschodnich, funkcjonującym na styku interesów Zachodu i Rosji. Wszystkie te uwarunkowania polityczne i gospodarcze mają określone konsekwencje dla Polski. Możemy je analizować w trzech głównych aspektach: gospodarczym, bezpieczeństwa i polityki regionalnej.

$\mathrm{W}$ odniesieniu do pierwszego z wymienionych aspektów należy zauważyć, że Polska obecnie nie wykorzystuje dostatecznie potencjału rynku ukraińskiego. Procentowy udział tego rynku w wymianie handlowej z Polską jest niewielki według danych statystycznych Ministerstwa Rozwoju dotyczących okresu styczeńczerwiec 2017 r. w eksporcie wynosił 2,08\%, a w imporcie 1,06\% (Syntetyczna informacja... 2017, s. 8). Tym samym wymiana handlowa z Ukrainą zamknęła się dla Polski dodatnim saldem, wynoszącym 1022,4 mln EUR, a dynamika wzrostu eksportu w pierwszym półroczu 2017 r. wyniosła 142\%. Analizując odpowiednie dane za cały 2016 r., uzyskujemy potwierdzenie wcześniej sformułowanej tezy, że potencjał i wielkość rynku ukraińskiego nie są dostatecznie dobrze wykorzystywane przez polskich przedsiębiorców - wartość polskiego eksportu w 2016 r. wyniosła 3461,7 mln EUR, a importu 1829,7 mln EUR, co stanowiło odpowiednio $1,87 \%$ i $1,01 \%$ całości sprzedaży i zakupów zagranicznych (Syntetyczna informacja... 2017, s. 8). Skumulowana wartość polskich inwestycji zagranicznych na Ukrainie w 2016 r. wyniosła 51,6 mln EUR, czyli jedynie 0,7\% całkowitej wartości wszystkich polskich inwestycji zagranicznych (Narodowy Bank Polski 2017).

Głównym problemem wpływającym na ograniczenie rozwoju wymiany handlowej między Polską a Ukrainą jest niestabilna sytuacja gospodarcza w drugim z wymienionych krajów. Do niekorzystnych czynników ostatnich kilku lat możemy zaliczyć: ujemną dynamikę wzrostu gospodarczego w latach 2014-2015 (odpowiednio $-6,6 \%$ i 2,3\%), wzrost poziomu inflacji do wartości $24,9 \%$ i 39,5\% w tych samych latach, wzrost stopy bezrobocia, jak również silny wzrost deficytu budżetowego i gwałtowne zwiększenie się długu publicznego w relacji do PKB (Kuśpit 2014, s. 249). Na rozwój gospodarczy Ukrainy negatywnie wpłynął też stale toczący się konflikt w obwodach ługańskim i donieckim, który znacząco obniżył 
potencjał gospodarczy całego kraju, a także uniemożliwił wywiązanie się z wielu kontraktów eksportowych. Ponadto problem we wzajemnych relacjach handlowych stanowiły takie czynniki, jak niestabilny kurs hrywny, wynikający ze stałej deprecjacji tej waluty w stosunku do głównych międzynarodowych walut oraz złotego, czy liczne bariery w handlu o charakterze protekcjonistycznym, np. wprowadzenie dodatkowych opłat importowych, embargo na niektóre produkty oraz globalny spadek zaufania w kwestii bezpieczeństwa biznesowego i inwestycyjnego na terytorium tego państwa, jak wcześniej wspomniano, częściowo objętego działaniami wojennymi (Kuśpit 2014, s. 251). Na ograniczenia importu produktów ukraińskich wpływa przede wszystkim przestarzały i oligarchiczny charakter gospodarki tego kraju, znacznie hamujący podaż produktów eksportowych, a ponadto ich niski poziom zaawansowania technologicznego (Yakubovskiy i in. 2017, s. 13). Głównymi produktami importowanymi do Polski są surowce i towary o niskim stopniu przetworzenia.

Analizując pozycję i znaczenie Ukrainy w wymiarze politycznym i regionalnym, należy podkreślić jej strategiczną rolę w relacjach Wschód-Zachód. Dokonując w 2014 r. aneksji Krymu, Rosja spowodowała destabilizację europejskiego i światowego systemu bezpieczeństwa międzynarodowego i pokazała światu imperialistyczny i mocarstwowy charakter swojej polityki zagranicznej. Żadne międzynarodowe konwencje nie upoważniały Rosji do podjęcia działań zbrojnych przeciwko niepodległemu krajowi, a tym bardziej do aneksji części jego terytorium. Postępowanie takie jawnie pogwałciło międzynarodowe reguły prawne, w tym również ustalenia Karty Narodów Zjednoczonych (Czaja 2016, s. 31-33). Należy przypuszczać, że działania Rosji w stosunku do Ukrainy ukierunkowane są głównie na zablokowanie jej zbliżenia z Zachodem, uniemożliwienie integracji ze strukturami UE oraz, co wydaje się szczególnie ważne w aspekcie mocarstwowych ambicji Rosji, uniemożliwienie przystąpienia Ukrainy do struktur NATO. Choć w sierpniu 2017 r. specjalny wysłannik Stanów Zjednoczonych ds. Ukrainy $\mathrm{K}$. Volker w udzielonym wywiadzie telewizyjnym stwierdził, że kraj ten jest jeszcze nieprzygotowany do przystąpienia do struktur północnoatlantyckich i NATO też nie jest na to gotowe, to już sam fakt rozważania członkostwa Ukrainy w Pakcie Północnoatlantyckim wydaje się dla Rosji podważeniem jej międzynarodowej pozycji na świecie i w regionie (Junko 2017). Aby powstrzymać imperialistyczne zapędy Rosji, cała międzynarodowa społeczność (przede wszystkim NATO i UE), wykorzystując swoje znaczne polityczne, gospodarcze i militarne możliwości, powinna podjąć skoordynowane działania mające na celu przywrócenie międzynarodowego poszanowania prawa, wartości oraz bezpieczeństwa niepodległych krajów (Czaja 2016, s. 35).

Ukraina zawsze będzie dla Polski strategicznym partnerem gospodarczym, politycznym i kulturowym z uwagi na sąsiedztwo obu krajów. W tym kontekście 
polityka Polski w stosunku do Ukrainy powinna być nastawiona na partnerstwo i współpracę, przede wszystkim zaś na popieranie europejskich aspiracji wschodniego sąsiada. Wydarzenia z 2013 r. pokazały, że znaczna część społeczeństwa ukraińskiego jest prozachodnia, a tym samym poszukuje swej tożsamości w zjednoczonej Europie. W 2014 r. Ukraina i UE podpisały układ stowarzyszeniowy, który zaczął obowiązywać 1 stycznia 2016 r. (The Trade Part... 2015). Należy przypomnieć, że to właśnie brak woli podpisania przez prezydenta W. Janukowycza wynegocjowanej wcześniej umowy stał się bezpośrednim powodem rozpoczęcia protestów na Euromajdanie i w konsekwencji - zmian politycznych na Ukrainie (Kuśpit 2014, s. 252). Ostatecznie podpisany układ otworzył nową kartę w rozwoju stosunków między UE a Ukrainą, promując głębsze więzi polityczne, silniejsze powiązania gospodarcze i poszanowanie wspólnych wartości. Część handlowa układu, ustanawiająca pogłębioną i rozszerzoną strefę wolnego handlu (DCFTA - Deep and Comprehensive Free Trade Areas), stwarza podstawy współpracy gospodarczej Ukrainy z krajami Europy, w tym UE. Najważniejsze ustalenia układu dotyczą wymiany handlowej, ale układ odnosi się ponadto do współpracy na takich płaszczyznach, jak: polityka zagraniczna, wymiar sprawiedliwości, wolność i bezpieczeństwo (w tym migracja), podatki, zarządzanie finansami publicznymi, nauka i technologia, edukacja i społeczeństwo informacyjne (Ukraina: Rada zatwierdza... 2017).

Zbliżenie Ukrainy do UE ma również duże znaczenie regionalne, w tym dla Polski. Polska ma szczególną szansę na odegranie roli pomostu pomiędzy słabiej rozwiniętą gospodarczo Ukrainą a wysoko rozwiniętymi krajami Europy Zachodniej, na uczestniczenie w transformacji gospodarczej, politycznej i społecznej Ukrainy, a tym samym na skorzystanie na potencjalnie wysokiej dynamice wzrostu gospodarczego i popytu wewnętrznego. Nie bez znaczenia pozostają też kwestie bezpieczeństwa w kontekście sąsiedztwa z prowadzącą mocarstwową politykę Rosją. Stabilność gospodarcza i polityczna Ukrainy wpłynęłaby na poprawę bezpieczeństwa w regionie, a także na wspólny rozwój oraz wzrost znaczenia Europy Środkowo-Wschodniej na arenie międzynarodowej.

\section{Podsumowanie}

Po rewolucji, jaka miała miejsce na Ukrainie w związku z wydarzeniami na Majdanie w 2013 r., kraj ten stanął w obliczu politycznych i gospodarczych wyborów pomiędzy zdominowaną i akceptowaną przez część społeczeństwa strefą wpływów Rosji a silnymi prounijnymi ambicjami głównie obywateli zachodniej części kraju. Wydarzenia te sprowokowały aneksję Krymu przez Rosję oraz wybuch zbrojonego konfliktu w separatystycznych regionach na wschodzie kraju, 
a także wpłynęły destabilizująco na światową równowagę sił. Podważenie przez obce mocarstwo integralności granic niepodległego kraju ukazało światu słabość międzynarodowych porozumień i układów oraz doprowadziło do poważnego międzynarodowego kryzysu politycznego, który nadal trwa. Można powiedzieć, że wydarzenia te kreślą przyszły kierunek zdarzeń na Ukrainie, wydaje się zatem, że perspektywa realnej poprawy sytuacji i skuteczności wprowadzanych reform jest odległa. Gospodarka Ukrainy opiera się głównie na przetwórstwie surowców, w tym na produkcji stali, która dodatkowo została znacznie zachwiana niestabilną sytuacją polityczną we wschodnich, zasobnych w węgiel, obwodach. Chociaż najnowsze dane makroekonomiczne dotyczące lat 2016-2017 wskazują na znaczną poprawę wskaźników ekonomicznych, takich jak: stopa wzrostu gospodarczego, poziom inflacji, deficyt budżetowy i dług publiczny, a także świadczą o wzroście produkcji przemysłowej i poprawie stabilności kursu hrywny, to gospodarka ta pilnie potrzebuje skutecznych reform oraz transformacji w kierunku sektorów zaawansowanych technologii, gwarantujących wyższe wartości dodane i lepszą rentowność. Ważnym problemem społecznym jest też niskie PKB per capita, które jest bezpośrednim powodem ubóstwa dużej części społeczeństwa i znacznie ogranicza wewnętrzny popyt. Gospodarka Ukrainy potrzebuje więc szybkiego zbliżenia z gospodarkami krajów UE, jak również efektywnego napływu bezpośrednich inwestycji zagranicznych, które mogłyby przyspieszyć proces transformacji ekonomicznej.

Dla Polski uwarunkowania polityczne i gospodarcze na Ukrainie są bardzo złożone, tzn. w ujęciu regionalnym zarówno stwarzają duże szanse, jak i stanowią poważne zagrożenie. Pod względem politycznym konflikt u granic Polski jest problemem, jeśli chodzi o bezpieczeństwo, gdyż wymusza wzmożoną czujność i wymaga umiędzynarodowienia procesów stabilizacyjnych. W dziedzinie gospodarki zaś analizowana sytuacja stwarza szansę na ekspansję handlową na bardzo chłonny i perspektywiczny rynek oraz na atrakcyjne inwestycje zagraniczne. Zarówno dla Ukrainy, jak i dla Polski, jako jej strategicznego partnera gospodarczego, zbliżenie Ukrainy do struktur UE, a w przyszłości członkostwo w tej organizacji wydają się kluczowe dla bezpieczeństwa i rozwoju gospodarczego regionu.

\section{Literatura}

Boczi A. (2014), Szara strefa na Ukrainie: przyczyny i środki zaradcze, Międzynarodowe Centrum Studiów Politycznych, Warszawa.

Chermack T.J., Kasshanna B.K. (2007), The Use and Misuse of SWOT Analysis and Implications for HRD Professionals, „Human Resource Development International”, vol. 10, nr 4, https://doi.org/10.1080/13678860701718760. 
Czaja J. (2016), Rosyjska agresja na Ukrainę: konsekwencje międzynarodowe (w:) Bezpieczeństwo subregionu Europy Środkowej $i$ Wschodniej w kontekście konfliktu na Ukrainie, red. T. Kubaczyk, M. Żyła, Wydawnictwo Akademii Obrony Narodowej, Warszawa.

European Commission, Directorate-General for Trade (2017), http://trade.ec.europa.eu/ doclib/docs/2006/september/tradoc_111613.pdf (data dostępu: 6.01.2018).

The Global Competitiveness Report 2016-2017 (2016), red. K. Schwab, World Economic Forum, Geneva.

Havrylyshyn O. (2014), A Quarter Century of Economic Reforms in Ukraine: Too Late, Too Little, Too Slow?, „mBank - CASE Seminar Proceedings”, nr 135.

Junko J. (2017), Wysłannik USA ds. Ukrainy: Ukraina nie jest gotowa do członkostwa w NATO, https://www.bankier.pl/wiadomosc/Wyslannik-USA-ds-Ukrainy-Ukrainanie-jest-gotowa-do-czlonkostwaw-NATO-3734849.html (data dostępu: 5.11.2017).

Kuśpit J. (2016), Wpływ sytuacji polityczno-ekonomicznej na Ukrainie na stosunki gospodarcze z Polska, ,,Rocznik Instytutu Europy Środkowo-Wschodniej”, vol. 14, nr 5.

Meshko N.P., Kostiuchenko M.K. (2015), Prospects of IT Sector Development as a Leading Innovative Sector in Ukraine, ,The Bulletin of the Dniepropetrovsk University. Series: Management of Innovations”, nr 4, https://doi.org/10.15421/191510.

Narodowy Bank Polski (2017), http://www.nbp.pl/home.aspx?f=/publikacje/pib/pib.html (data dostępu: 3.11.2017).

Statistics Explained (2016), Eurostat, http://ec.europa.eu/eurostat/statisticsexplained/ index.php/File:Gross_domestic_product_(GDP),_2005\%E2\%80\%9315_ENPE16.png (data dostępu: 20.12.2017).

Statistics on European Neighbourhood Policy Countries: East - 2018 Edition (2018), Publications Office of the European Union, Luxembourg, https://ec.europa.eu/eurostat/ documents/3217494/9033104/KS-02-18-351-EN-N.pdf/d7ef566c-ba67-4bf4-9b68-5adda18043c3 (data dostępu: 2.11.2018).

Syntetyczna informacja o eksporcie i imporcie Polski styczeń-grudzień 2016 (2017), Ministerstwo Rozwoju, Departament Strategii Rozwoju, Warszawa.

The Trade Part of the EU-Ukraine Association Becomes Operational on 1 January 2016 (2015), European Commission, http://trade.ec.europa.eu/doclib/press/index. cfm?id=1425 (data dostępu: 14.02.2018).

Ukraina: Rada zatwierdza układ o stowarzyszeniu UE - Ukraina (2017), http://www.consilium.europa.eu/pl/press/press-releases/2017/07/11/ukraine-association-agreement/ (data dostępu: 6.03.2018).

Yagelskaya Yu K. (2013), Krajowe modele systemów gospodarczych: tworzenie, zarzq̨dzanie, transformacja (w:) Materiały Międzynarodowe Konferencji Naukowo-Praktycznej, red. K.S. Shaposhnikov, Wydawnictwo „Helvetica”, Kielce.

Yakubovskiy M., Liashenko V., Kamińska B., Kvilinskyi O. (2017), Economy Modernization of Industrial Regions (Based on the Example of Ukraine) (w:) Economic Transformation in Ukraine: Comparative Analysis and European Experience, red. P. Głowski, O. Kvilinskyi, Institute for International Cooperation Development, Warszawa. 


\section{Ukraine in the Face of Economic and Political Challenges}

(Abstract)

The article presents the current economic and social situation of Ukraine and the possible scenarios for its future development. It seems that deep structural reforms, rapprochement with EU and ending the conflict in the Donbas are essential to improving Ukraine's standard of living and sense of security. These processes are very complicated and render significant progress in the near term unlikely. The crisis in Ukraine has an important impact on neighbouring Poland, for which this publication reviews the potential economic and social implications.

Keywords: Ukraine, crisis in Ukraine, development of Ukrainian economy, PolandUkraine relation. 